\title{
ВПЛИВ ЗОНАЛЬНОСТІ СТОВБУРА НА ТРИБОТЕХНІЧНІ ХАРАКТЕРИСТИКИ ПАРИ ТЕРТЯ "ДЕРЕВИНА - СТАЛЬ 3 ЙОННО-ПЛАЗМОВИМ ПОКРИТТЯМ"
}

\begin{abstract}
Наведено результати досліджень сили тертя, інтенсивності зношування та сили різання сталі Р6М5 з йонно-плазмовими покриттями. Показано, що їх нанесення на інструмент, що працює в контакті з деревиною, істотно зменшує ці показники. Виявлено, що діапазон зміни сили тертя вздовж волокон залежно від розташування зразка за висотою стовбура корелює 3 діапазоном зміни торцевої твердості, а зменшення сили тертя інденторів 3 йонно-плазмовими покриттями порівняно 3 іншими методами зміцнення, не залежить від того, з якої висоти стовбура взято зразок і становить 1,5...2,9 раза для дуба; $1,5 \ldots .3,1$ для бука; $1,3 \ldots 3,1$ - для сосни; 1,4 ...3,5 - для ялиці. Встановлено, що під час тертя поперек волокон діапазон зміни сили тертя залежно від розташування зразка за висотою стовбура не корелює з діапазоном зміни твердості, тобто в листяних порід сила тертя $\epsilon$ меншою від того значення, яке можна було б спрогнозувати, грунтуючись на співвідношенні твердості зразків у різних частинах стовбура. Для визначення відхилення від очікуваного значення сили тертя введено коефіцієнт відповідності. Наведено причини відносного зменшення опору тертю. З'ясовано, що під час тертя індентора 3 покриттям по вологій деревині сила тертя зменшується для всіх досліджуваних порід на будь-якій висоті стовбура в 1,7 ...2,3 раза. Найменше значення сили тертя $0,1 \mathrm{H} \cdot 10^{-2}$ зафіксовано в парі тертя "покриття Ti-Ni-N+TiN - зразок із верхньої частини стовбура ялиці" після шести проходів індентора вздовж волокон. Результати досліджень з визначення інтенсивності зношування та сили тертя показали, що значення цих величин зменшуються в послідовності (Ti-Ni-N) - (TiN) - (Ti+TiN) - (Ti-Ni-N+TiN) за всіх варіантів співвідношення режимних параметрів різання.
\end{abstract}

Ключові слова: сила тертя; висота стовбура; індентор; коефіцієнт відповідності; інтенсивність зношування; сила різання.

Вступ. Технологію вакуумного йонно-плазмового напилення способом конденсації речовини 3 йонним бомбардуванням (КІБ) часто застосовують у різних галузях. Її використовують не тільки в машинобудуванні, але і в електротехніці, харчовій, легкій промисловості тощо й є одним із найперспективніших способів поверхневого зміцнення інструменту, деталей та вузлів машин і технологічного оснащення. Це стало причиною великої кількості досліджень у кількох напрямах, основними 3 яких є вдосконалення конструкції установок для напилення, дослідження фізико-хімічних процесів під час переносу матеріалу катоду на підкладку, покращення фізико-механічних властивостей та експлуатаційних характеристик одержаних покриттів. Водночас ще недостатньо вивчено процеси, що відбуваються під час контакту з деревиною інструменту та деталей 3 такими покриттями. Очевидно, що перебіг цих процесів відрізняється від тих, що є в парі "метал - метал" внаслідок того, що деревина - це складний багатокомпонентний матеріал $з$ анізотропією властивостей як в осьовому, так і в радіальному напрямку. Важливими 3 цього погляду є дослідження сили тертя та сили різання, що є основою для визначення теплового балансу в зоні різання, а також розрахунку на міцність інструменту та вузлів механізмів різання та подавання.

Матеріали й методи дослідження. Дослідження сили тертя проводили на трибометрі ТМ-90 за методикою (Bilous et al., 1999). Циліндричний індентор діаметром 3 мм 3 конусом за вершини 3 радіусом заокруглення 0,5 мм виготовлено зі сталі Р6М5. На робочу поверхню індентора наносили йонно-плазмове покриття на установці "Булат-3Т" під час дотримування режимних параметрів, які наведено в табл. 1.

Зразки деревини мають форму паралелепіпеда розміром $32 \times 16 \times 5$ мм. Їх виготовлено 3 деревини сосни, ялиці, бука і дуба з поздовжнім і поперечним розміщенням волокон у сухому (вологість $12 \%$ ) і вологому (вологість 38 \%) стані з нижньої, середньої та верхньої часин стовбура за методикою (Sopushynskyi, 1999). Твердість деревини визначали за методом Янка. Силу тертя Fmp фіксували під час разового проходу індентора

Інформація про авторів:

Гасій Олександр Богданович, канд. техн. наук, доцент, кафедра технології матеріалів та машинобудування.

Email: o.hasiy@gmail.com

Сопушинський Іван Миколайович, д-р с.-г. наук, доцент, кафедра ботаніки, деревинознавства та недеревних ресурсів лісу. Email: sopushynskyy@ukr.net

Білоус Олексій Володимирович, канд. техн. наук, доцент, кафедра прикладного матеріалознавства та обробки матеріалів. Email: volod_11@ukr.net

Цитування за ДСТУ: Гасій О. Б., Сопушинський І. М., Білоус О. В. Вплив зональності стовбура на триботехнічні характеристики пари тертя "деревина - сталь з йонно-плазмовим покриттям". Науковий вісник НЛтУ України. 2018, т. 28, № 11. С. 96-100.

Citation APA: Hasiy, O. B., Sopushynskyy, I. M., \& Bilous, O. V. (2018). Effect of trunk zonality on tribotechnical characteristics of friction pair "wood - steel with ion-plasma coating". Scientific Bulletin of UNFU, 28(11), 96-100. https://doi.org/10.15421/40281118 
$\left(F m p_{1}\right)$ і після шести проходів $\left(F m p_{6}\right)$ у разі навантаження $0,3 \mathrm{H}$ і зворотно-поступального руху індентора з середньою швидкістю $0,02 \mathrm{~m} / \mathrm{c}$. Результати експериментів, одержані на зразках $з$ йонно-плазмовими покриттями, порівнювали з результатами, одержаними на зраз- ках зі сталі Р6М5, зміцнених лазерною обробкою; 3 електроіскровим покриттям системи $\mathrm{Fe}-\mathrm{Mn}-\mathrm{C}-\mathrm{B}-\mathrm{Si}-\mathrm{Cr}$ (ЕІЛ); тим же покриттям, зміцненим лазерною обробкою (ЕІЛ+ОКГ), що були отримані за методикою (Bilous et al., 1999), та незміцненою сталлю Р6М5.

Табл. 1. Режими осадження вакуумних конденсатів

\begin{tabular}{|c|c|c|c|c|c|c|c|c|}
\hline \multirow{2}{*}{$\begin{array}{l}\text { № пок- } \\
\text { риття }\end{array}$} & \multirow{2}{*}{$\begin{array}{c}\text { Компонент } \\
\text { покриття }\end{array}$} & \multicolumn{2}{|c|}{$\begin{array}{c}\text { Матеріал випаровувача і } \\
\text { струм дуги, А } \\
\end{array}$} & \multirow{2}{*}{ Робочий газ } & \multirow[t]{2}{*}{ Тиск газу, Па } & \multirow{2}{*}{$\begin{array}{c}\text { Опорна } \\
\text { напруга, В }\end{array}$} & \multirow{2}{*}{$\begin{array}{r}\text { Температура } \\
\text { підкладки, }{ }^{\circ} \mathrm{C}\end{array}$} & \multirow{2}{*}{$\begin{array}{c}\text { Товщина } \\
\text { покриття, } \\
\text { мкм }\end{array}$} \\
\hline & & I випаровувач & II випаровувач & & & & & \\
\hline KІБ1 & TiN & $\mathrm{Ti} / 100$ & - & $\mathrm{N}_{2}$ & $0,4 \ldots 0,5$ & 150 & 350 & $5 \ldots 6$ \\
\hline КІБ2 & Ti+TiN & $\mathrm{Ti} / 100$ & - & $\mathrm{N}_{2}$ & $0,4 \ldots 0,5$ & 150 & 350 & $5 \ldots 6$ \\
\hline КІБ3 & Ti-Ni-N & $\mathrm{Ti} / 100$ & $\left.\mathrm{Ni} / 70^{*}\right)$ & $\mathrm{N}_{2}$ & $0,4 \ldots 0,5$ & 150 & 400 & $5 \ldots 6$ \\
\hline \multirow{2}{*}{ КІБ4 } & \multirow{2}{*}{$\begin{array}{l}\text { Ti-Ni-N + } \\
\text { TiN }\end{array}$} & $\mathrm{Ti} / 100$ & $\left.\mathrm{Ni} / 100^{* *}\right)$ & $-1 "-$ & $-"-$ & 200 & 400 & \multirow{2}{*}{$6 \ldots 7$} \\
\hline & & $\mathrm{Ti} / 100$ & - & $\mathrm{N}_{2}$ & $0,4 \ldots 0,5$ & 150 & 350 & \\
\hline
\end{tabular}

Примітка: ${ }^{*)}$ - напилення 3 нікелевого катода $з$ суцільним сепаратором; $\left.{ }^{* *}\right)$ - напилення 3 нікелевого катода зі щілинним сепаратором.

Інтенсивність зношування сталевих зразків із досліджуваними покриттями визначали ваговим способом під час моделювання процесу різання зразків із деревини дуба діаметром 100 мм і висотою 25 мм на машині тертя МТ-68 за методикою (Bilous et al., 2001). Залежність головної складової сили різання $F_{z}$ від елементів режиму різання визначали за методикою (Bilous et al., 2001) за допомогою динамометра ДК-600 у процесі точіння на токарно-гвинторізному верстаті 1 К62 дубової заготовки діаметром 180 мм прохідними токарними різцями з досліджуваними покриттями.

Результати дослідження та їх обговорення. Вибір для визначення сили тертя контртіла 3 деревини сосни звичайної (Pinus sylvestris), ялиці білої (Abies alba), бука лісового (Fagus sylvatica), дуба звичайного (Quercus robur) обгрунтовано певними міркуваннями. Сосна займає близько 35 \% державного лісового фонду України, дуб $-26,3 \%$, бук - 9,3\%, ялиця $-1,4 \%$. Головними напрямами їх використання є будівництво, вагонобудування, виробництво тари (сосна), меблів, фанери, паркету (дуб, бук). Незважаючи на невелику розповсюдженість, ялицю використовують у виробництві столярних виробів, музичних інструментів, а особливо в паперово-целюлозній промисловості завдяки тому, що іiї деревина практично не містить смоли. Окрім цього, відтворено видову та зональну різноманітність: представлено хвойні породи, що містять ядро та заболонь (сосна) і тільки заболонь (ялиця); листяну породу кільце-судинну, що містить ядро та заболонь (дуб) і розсіяно судинну, що містить тільки заболонь (бук).

Результати досліджень сили тертя засвідчили (табл. 2), що для зразків з йонно-плазмовими покриттями зі збільшенням кількості проходів індентора сила тертя під час тертя як вздовж волокон, так і поперек них зростає $\left(F m p_{1}<F m p_{6}\right)$, що пов'язано з неодноразовою деформацією волокон.

У разі тертя вздовж волокон усі чотири досліджувані покриття, одержані методом КІБ, переважають незміцнену сталь Р6М5; цю ж сталь, зміцнену електроіскровим легуванням або лазерною обробкою; і поступаються лише комбінованій обробці ЕІЛ + ОКГ. Зменшення сили тертя йонно-плазмових покриттів, порівняно $з$ іншими методами зміцнення, не залежить від того, 3 якої висоти стовбура взято зразок і становить від 1,5 до 2,9 раза для дуба; $1,5 \ldots 3,1$ - для бука; $1,3 \ldots 3,1$ для сосни; 1,4 ...3,5 - для ялиці (рисунок). Діапазон зміни сили тертя вздовж волокон залежно від розташування зразка за висотою стовбура корелює 3 діапазоном зміни торцевої твердості та є більшим від нього на $1 . .3 \%$.

Табл. 2. Сила тертя пари "сталь - деревина" $(V=0,02 \mathrm{м} / \mathrm{c} ; \boldsymbol{P}=0,3 \mathrm{H})$ і твердість зразків

\begin{tabular}{|c|c|c|c|c|}
\hline \multirow{4}{*}{$\begin{array}{l}\text { Матеріал індентора } \\
\text { і тип покриття }\end{array}$} & \multicolumn{4}{|c|}{ Матеріал деревини і напрямок волокон } \\
\hline & \multicolumn{2}{|c|}{ вздовж } & \multicolumn{2}{|c|}{$\begin{array}{r}\text { поперек } \\
\text { Fqn } \text { H.1 }^{-2}\end{array}$} \\
\hline & \multicolumn{4}{|c|}{ Сила тертя $F m p, \mathrm{H} \cdot 10^{-2}$} \\
\hline & $F m p_{1}$ & $F_{m p} p_{6}$ & $F m p_{1}$ & $\mathrm{Fmp}_{6}$ \\
\hline 1 & 2 & 3 & 4 & \\
\hline \multicolumn{5}{|c|}{ Дуб - нижня частина стовбура } \\
\hline & \multicolumn{2}{|c|}{$H=69,9 \mathrm{M \Pi а}$} & \multicolumn{2}{|c|}{$H=51,1 \mathrm{M \Pi а}$} \\
\hline Сталь Р6М5 & 8,55 & 9,80 & 10,0 & 12,2 \\
\hline P6М5+ЕІЛ & 10,6 & 10,3 & 12,2 & 11,7 \\
\hline P6M5+OKГ & 10,6 & 9,65 & 12,2 & 10,2 \\
\hline Р6М5+(ЕІЛ+ОКГ) & 3,65 & 3,70 & 4,6 & 4,6 \\
\hline P6М5+КІБ1 & 4,75 & 5,85 & 4,1 & 5,6 \\
\hline P6М5+КІБ2 & 4,15 & 5,25 & 3,6 & 5,1 \\
\hline P6M5+KIБ3 & 5,25 & 6,35 & 4,6 & 6,1 \\
\hline P6М5+КІБ4 & 3,65 & 4,75 & 3,05 & 4,6 \\
\hline \multicolumn{5}{|c|}{ Дуб - середня частина стовбура } \\
\hline & \multicolumn{2}{|c|}{$H=66,5 \mathrm{M \Pi а}$} & \multicolumn{2}{|c|}{$H=48,5 \mathrm{MПа}$} \\
\hline Сталь Р6М5 & 8,0 & 9,0 & 5,5 & 12,0 \\
\hline Р6М5+ЕІЛ & 10,0 & 9,5 & 12,0 & 11,5 \\
\hline P6M5+OKГ & 10,0 & 9,0 & 12,0 & 10,0 \\
\hline Р6М5+(ЕІЛ+ОКГ) & 3,5 & 3,5 & 4,5 & 4,5 \\
\hline P6М5+КІБ1 & 4,5 & 5,5 & 4,0 & 5,5 \\
\hline P6М5+KIБ2 & 4,0 & 5,0 & 3,5 & 5,0 \\
\hline P6М5+КІБ3 & 5,0 & 6,0 & 4,5 & 6,0 \\
\hline P6М5+KIБ4 & 3,5 & 4,5 & 3,0 & 4,5 \\
\hline \multicolumn{5}{|c|}{ Дуб - верхня частина стовбура } \\
\hline & \multicolumn{2}{|c|}{$H=63,3 \mathrm{M \Pi а}$} & \multicolumn{2}{|c|}{$H=46,2 \mathrm{M \Pi а}$} \\
\hline Сталь Р6М5 & 7,8 & 8,9 & 8,8 & 10,8 \\
\hline Р6М5+ЕІЛ & 9,6 & 9,3 & 10,8 & 11,5 \\
\hline P6M5+OKГ & 9,6 & 8,7 & 10,8 & 9,0 \\
\hline Р6М5+(ЕІЛ+ОКГ) & 3,3 & 3,4 & 4,05 & 4,05 \\
\hline P6М5+КІБ1 & 4,3 & 5,3 & 3,6 & 5,0 \\
\hline P6М5+KІБ2 & 3,75 & 4,75 & 3,15 & 4,5 \\
\hline P6М5+КІБ3 & 4,75 & 5,75 & 4,1 & 5,4 \\
\hline P6М5+КІБ4 & 3,3 & 4,25 & 2,7 & 4,1 \\
\hline \multicolumn{5}{|c|}{ Бук - нижня частина стовбура } \\
\hline & \multicolumn{2}{|c|}{$H=71,0 \mathrm{M \Pi а}$} & \multicolumn{2}{|c|}{$H=53,5 \mathrm{M \Pi а}$} \\
\hline Сталь Р6М5 & 9,1 & 9,8 & 9,3 & 10,8 \\
\hline Р6М5+ЕІЛ & 9,5 & 9,2 & 9,8 & 10,3 \\
\hline P6M5+OKГ & 9,0 & 8,1 & 10,3 & 9,8 \\
\hline Р6М5+(ЕІЛ+ОКГ) & 3,7 & 2,65 & 4,1 & 3,6 \\
\hline P6М5+КІБ1 & 4,2 & 4,7 & 4,6 & 5,2 \\
\hline P6М5+KІБ2 & 3,65 & 4,2 & 4,1 & 4,6 \\
\hline P6М5+KIБ3 & 4,75 & 5,3 & 5,2 & 5,7 \\
\hline P6М5+КІБ4 & 3,1 & 3,65 & 3,6 & 4,1 \\
\hline \multicolumn{5}{|c|}{ Бук - середня частина стовбура } \\
\hline & \multicolumn{2}{|c|}{$H=67,7 \mathrm{M \Pi а}$} & \multicolumn{2}{|c|}{$H=51,2 \mathrm{M \Pi а}$} \\
\hline Сталь Р6М5 & 8,5 & 9,0 & 9,0 & 10,5 \\
\hline Р6М5+ЕІЛ & 9,0 & 8,5 & 9,5 & 10,0 \\
\hline P6M5+OKГ & 8,5 & 7,5 & 10,0 & 9,5 \\
\hline P6М5+(ЕІЛ+OКГ) & 3,5 & 2,5 & 4,0 & 3,5 \\
\hline P6М5+КІБ1 & 4,0 & 4,5 & 4,5 & 5,0 \\
\hline
\end{tabular}




\begin{tabular}{|c|c|c|c|c|}
\hline 1 & 2 & 3 & 4 & 5 \\
\hline P6М5+КІБ2 & 3,5 & 4,0 & 4,0 & 4,5 \\
\hline P6М5+КІБ3 & 4,5 & 5,0 & 5,0 & 5,5 \\
\hline P6М5+КІБ4 & 3,0 & 3,5 & 3,5 & 4,0 \\
\hline \multicolumn{5}{|c|}{ Бук - верхня частина стовбура } \\
\hline & \multicolumn{2}{|c|}{$H=64,6 \mathrm{MПа}$} & \multicolumn{2}{|c|}{$H=48,8 \mathrm{MПа}$} \\
\hline Сталь Р6М5 & 8,2 & 8,9 & 8,3 & 9,7 \\
\hline Р6М5+ЕІЛ & 8,65 & 8,35 & 8,7 & 9,2 \\
\hline P6M5+OKГ & 8,15 & 7,25 & $\overline{9,2}$ & 8,7 \\
\hline Р6М5+(ЕІЛ+ОКГ) & 3,25 & 2,4 & 3,7 & 3,2 \\
\hline P6М5+КІБ1 & 3,8 & 4,3 & 4,1 & 4,6 \\
\hline P6М5+КІБ2 & 3,1 & 3,8 & 3,7 & 4,1 \\
\hline P6М5+КІБ3 & 4,25 & 4,8 & 4,6 & 5,1 \\
\hline P6М5+КІБ4 & 2,8 & 3,25 & 3,2 & 3,7 \\
\hline \multicolumn{5}{|c|}{ Сосна - нижня частина стовбура } \\
\hline & \multicolumn{2}{|c|}{$H=29,2 \mathrm{M \Pi а}$} & \multicolumn{2}{|c|}{$H=24,6 \mathrm{M \Pi а}$} \\
\hline Сталь Р6М5 & 7,4 & 8,1 & 9,3 & 9,2 \\
\hline Р6М5+ЕІЛ & 7,9 & 7,5 & 9,2 & 8,6 \\
\hline P6M5+OKГ & 5,75 & 6,35 & 5,4 & 7,0 \\
\hline Р6М5+(ЕІЛ+ОКГ) & 2,6 & 2,1 & 3,2 & 2,7 \\
\hline P6М5+КІБ1 & 3,65 & 4,0 & 4,3 & 4,9 \\
\hline P6М5+КІБ2 & 3,1 & 3.65 & 3,8 & 4,3 \\
\hline P6М5+КІБ3 & 4,15 & 4,75 & 4,9 & 5,4 \\
\hline P6М5+КІБ4 & 2,55 & 3,1 & 3,2 & 3,8 \\
\hline \multirow{2}{*}{\multicolumn{5}{|c|}{ Сосна - середня частина стовбура }} \\
\hline & & & $H=$ & ИПа \\
\hline Сталь Р6М5 & 7,0 & 7,5 & 8,0 & 8,5 \\
\hline Р6М5+ЕІЛ & 7,5 & 7,0 & 8,5 & 8,0 \\
\hline P6M5+OKГ & 5,5 & 6,0 & 5,0 & 6,5 \\
\hline$\overline{\mathrm{P} 6 \mathrm{M} 5+(\text { ЕІЛ+ОКГ })}$ & 2,5 & 2,0 & 3,0 & 2,5 \\
\hline P6М5+KIБ1 & 3,5 & 4,0 & 4,0 & 4,5 \\
\hline P6М5+КІБ2 & 3,0 & 3,5 & 3,5 & 4,0 \\
\hline P6М5+КІБ3 & 4,0 & 4,5 & 4,5 & 5,0 \\
\hline P6М5+КІБ4 & 2,5 & 3,0 & 3,0 & 3,5 \\
\hline \multicolumn{5}{|c|}{ Сосна - верхня частина стовбура } \\
\hline & \multicolumn{2}{|c|}{$H=26,7 \mathrm{M \Pi а}$} & \multicolumn{2}{|c|}{$H=22,4 \mathrm{M}$ Па } \\
\hline Сталь P6M5 & 6,8 & 7,4 & 7,8 & 8,3 \\
\hline Р6М5+ЕІЛ & 7,2 & 6,9 & 8,3 & 7,8 \\
\hline P6M5+OKГ & 5,3 & 5,8 & 4,9 & 6,4 \\
\hline Р6М5+(ЕІЛ+OКГ) & 2,4 & 1,9 & 2,9 & 2,4 \\
\hline P6М5+КІБ1 & 3,3 & 3,8 & 3,9 & 4,4 \\
\hline P6М5+КІБ2 & 2,8 & 3,3 & 3,4 & 3,9 \\
\hline P6М5+КІБ3 & 3,8 & 4,3 & 4,4 & 4,9 \\
\hline P6М5+KIБ4 & 2,35 & 2,8 & 2,9 & 3,4 \\
\hline Ялиц & НИЖІ & астина & вбуура & \\
\hline & $H=$ & МПа & $H=$ & ИПа \\
\hline Сталь Р6М5 & 7,0 & 7,6 & 6,0 & 6,4 \\
\hline Р6М5+ЕІЛ & 7,4 & 7,0 & 6,4 & 6,0 \\
\hline P6M5+OKГ & 5,3 & 6,0 & 3,7 & 4,9 \\
\hline Р6М5+(ЕІЛ+OКГ) & 2,1 & 1.6 & 2,3 & 1,9 \\
\hline P6М5+КІБ1 & 3,1 & 4,0 & 3,0 & 3,4 \\
\hline P6М5+КІБ2 & 2,6 & 3,1 & 2,7 & 3,3 \\
\hline Р6М5+КІБ3 & 3,6 & 4,25 & 3,5 & 3,7 \\
\hline P6М5+КІБ4 & 2,1 & 2,6 & 2,3 & 2,9 \\
\hline Ялиця & серед & астина & овбура & \\
\hline & $H=$ & МПа & $H=$ & ИПа \\
\hline Сталь Р6М5 & 6,5 & 7,0 & 5,6 & 6,0 \\
\hline Р6М5+ЕІЛ & 7,0 & 6,5 & 6,0 & 5,6 \\
\hline P6M5+OKГ & 5,0 & 5,5 & 3,5 & 4,55 \\
\hline Р6М5+(ЕІЛ+ОКГ) & 2,0 & 1,5 & 2,2 & 1,8 \\
\hline P6М5+КІБ1 & 3,0 & 3,5 & 2,8 & 3,15 \\
\hline P6М5+КІБ2 & 2,5 & 3,0 & 2,5 & 3,1 \\
\hline P6М5+КІБ3 & 3,5 & 4,0 & 3,3 & 3,5 \\
\hline P6М5+КІБ4 & 2,0 & 2,5 & 2,2 & 2,7 \\
\hline Ялиця & верх & астина & овбура & \\
\hline & $H=$ & $\mathrm{M \Pi а}$ & $H=$ & ИПа \\
\hline Сталь Р6М5 & 6,3 & 6,9 & 5,4 & 5,8 \\
\hline Р6М5+ЕІЛ & 6,7 & 6,4 & 5,8 & 5,4 \\
\hline P6M5+OKГ & 4,8 & 5,3 & 3,4 & 4,4 \\
\hline Р6M5+(ЕІЛ+ОКГ) & 1,9 & 1,4 & 2,1 & 1,7 \\
\hline P6М5+КІБ1 & 2,85 & 3,3 & 2,7 & 3,0 \\
\hline P6М5+КІБ2 & 2,35 & 2,85 & 2,4 & 3,0 \\
\hline P6М5+КІБ3 & 3,35 & 3,8 & 3,3 & 3,4 \\
\hline P6М5+КІБ4 & 1,9 & 2,3 & 2,1 & 2,6 \\
\hline
\end{tabular}

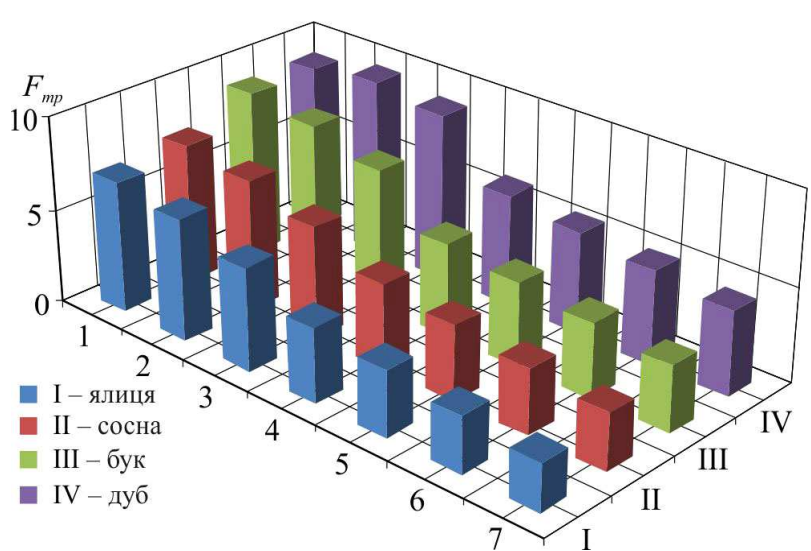

Рисунок. Сила тертя вздовж волокон після шести проходів індентора за зразками з середньої частини стовбура: 1) сталь Р6М5 незміцнена; 2) електроіскрове покриття; 3) зміцнення лазером; 4) Ti-Ni-N; 5) TiN; 6) Ti+TiN; 7) Ti-Ni-N+TiN

Під час тертя поперек волокон зберігається таке ж співвідношення між значеннями сили тертя покриттів, одержаними різними методами, що й під час тертя вздовж волокон. Проведено оцінювання наявності кореляції між діапазоном зміни сили тертя залежно від розташування зразка за висотою стовбура 3 діапазоном зміни твердості. Для визначення відхилення від очікуваного значення сили тертя введено коефіцієнт відповідності:

$$
K_{b}^{(i)}=\frac{K_{m}^{(i)}}{K_{c}^{(i)}}, i=\overline{1,3},
$$

де: $K_{m}^{(i)}-$ коефіцієнт твердості зразків у $i$-тої частини стовбура відносно твердості середньої частини (якщо й $=1-$ відповідає верхній частині стовбура, $i=2-$ середній, $i=3$ - нижній);

$$
K_{m}^{(i)}=\frac{H^{(i)}}{H_{2}}, i=\overline{1,3},
$$

де: $H^{(i)}$ - твердість зразків із $i$-тої частини стовбура; $H_{2}-$ твердість зразків із 2-ої (середньої) частини стовбура; $K_{c}^{(i)}-$ коефіцієнт сили тертя за зразком з $i$-тої частини стовбура відносно сили тертя за зразком із середньої частини;

$$
K_{c}^{(i)}=\frac{F_{m p}^{(i)}}{F_{m p}^{(2)}}, i=\overline{1,3},
$$

де: $F_{m p}^{(i)}$ - сила тертя за зразками з $i$-тої частини стовбура; $F_{m p}^{(2)}$ - сила тертя за зразками з 2-ої (середньої) частини стовбура.

Табл. 3. Значення коефіцієнта відповідності для зразків із різних частин стовбура піл час тертя поперек волокон

\begin{tabular}{|c|c|c|}
\hline \multirow{2}{*}{ Порода } & \multicolumn{2}{|c|}{ Коефіцієнт відповідності $K_{6}$} \\
\cline { 2 - 3 } & нижня частина стовбура & верхня частина стовбура \\
\hline Дуб & 1,03 & 1,06 \\
\hline Бук & 1,01 & 1,03 \\
\hline Сосна & 0,97 & 0,97 \\
\hline Ялиця & 0,98 & 0,97 \\
\hline
\end{tabular}

Виявлено, що діапазон зміни сили тертя залежно від розташування зразка за висотою стовбура не корелює 3 діапазоном зміни твердості (табл. 3). Так, сила тертя для листяних порід $є$ меншою від того значення, яке можна було б спрогнозувати, грунтуючись на співвідношенні твердості зразків у різних частинах стовбура, тобто $K_{s}^{(i)}>1$. Очевидно, що для середньої частини стовбура $K_{6}^{(i)}=1$. Причини відносного зменшення опору тертю можуть бути зумовлені наявністю таких речовин (Ugolev, 2001): 
1. Вміст лігніну, що зумовлює міцність стовбурів, у деревині сосни та ялиці $26 \ldots 30 \%$, а в дуба та бука$20 \ldots .24 \%$.

2. Інша речовина, яка позитивно впливає на міцність, - геміцелюлоза - всі породи, що аналізують, містять приблизно в однаковій кількості- $22 . .26 \%$. Вона складається 3 гексозанів $\left(\mathrm{C}_{6} \mathrm{H}_{10} \mathrm{O}_{5}\right)_{\mathrm{n}}$ і пентозанів $\left(\mathrm{C}_{5} \mathrm{H}_{8} \mathrm{O}_{4}\right)_{\mathrm{n}}$. Але вміст гексозанів із більшою молекулярною масою у хвойних породах вдвічі більший, ніж у листяних.

3. Також механічну функцію у хвойних породах виконують волокна трахеїд, довжина яких становить 4...6 мм. Волокна лібриформу, що виконують аналогічну функцію у листяних, мають довжину до 1 мм.

4. Своєрідними ребрами жорсткості дерев листяних порід $\epsilon$ серцевинні промені. У дуба їхній об'єм досягає $30 \%$, але зоріснтовані вони в радіальному напрямку, тому під час руху індентора поперек волокон не чинять істотного опору його переміщенню.

Під час тертя індентора 3 покриттям по вологій деревині сила тертя зменшується для всіх досліджуваних порід на будь-якій висоті стовбура в 1,7...2,3 раза, що можна пояснити тим, що волога відіграє роль мастильної речовини. Найменше значення сили тертя $0,1 \mathrm{H} \cdot 10$ 2 зафіксовано в парі тертя "покриття Ti-Ni-N+TiN - зразок із верхньої частини стовбура ялиці" після шести проходів індентора вздовж волокон.

Результати досліджень 3 визначення інтенсивності зношування показали (табл. 4), що вона зменшується в послідовності (Ti-Ni-N) - (TiN) - (Ti+TiN) - (Ti-Ni-N + $\mathrm{TiN})$ за всіма варіантами співвідношення режимних параметрів різання. Всі досліджувані йонно-плазмові покриття зношуються менш інтенсивно, ніж незміцнена сталь Р6М5, в 1,5..66,6 раза, причому цей діапазон розширюється із зростанням навантаження $(1,5 \ldots 5,8$ для $P$ $=10 \mathrm{H} ; 1,5 \ldots 6,2$ для $P=20 \mathrm{H} ; 1,7 \ldots 6,6$ для $P=30 \mathrm{H})$. Для швидкості різання така відповідність відсутня: найбільший діапазон підвищення стійкості інструменту $(1,5 \ldots 6,6)$ характерний для $V=6 \mathrm{~m} / \mathrm{c}$.

Табл. 4. Інтенсивність зношування зразків із покриттями

\begin{tabular}{|c|c|c|c|c|c|c|}
\hline \multirow{2}{*}{$\begin{array}{c}\text { Швид- } \\
\text { кість } \\
\text { різання } \\
V, \mathrm{~m} / \mathrm{c}\end{array}$} & \multirow{2}{*}{$\begin{array}{l}\text { Наван- } \\
\text { тажен- } \\
\text { ня } P, \mathrm{H}\end{array}$} & \multicolumn{5}{|c|}{ Інтенсивність зношування $I_{\text {зн }}$ мг/км } \\
\hline & & P6M5 & $\begin{array}{c}\text { P6M5+K } \\
\text { IБ1 }\end{array}$ & $\begin{array}{c}\text { P6M5+K } \\
\text { IБ2 }\end{array}$ & $\begin{array}{c}\text { P6M5+K } \\
\text { IБ3 }\end{array}$ & $\begin{array}{c}\text { P6M5+K } \\
\text { IБ4 }\end{array}$ \\
\hline 3 & 10 & 0,460 & 0,220 & 0,164 & 0,245 & 0,098 \\
\hline 6 & 10 & 0,075 & 0,033 & 0,022 & 0,049 & 0,013 \\
\hline 9 & 10 & 0,011 & 0,005 & 0,003 & 0,007 & 0,002 \\
\hline 3 & 20 & 0,965 & 0,426 & 0,352 & 0,535 & 0,223 \\
\hline 6 & 20 & 0,243 & 0,1 & 0,05 & 0,135 & 0,039 \\
\hline 9 & 20 & 0,100 & 0,056 & 0,037 & 0,068 & 0,027 \\
\hline 3 & 30 & 2,505 & 1,019 & 0,6 & 1,255 & 0,492 \\
\hline 6 & 30 & 0,850 & & & & 0,128 \\
\hline 9 & 30 & 0,250 & 0,109 & 0,078 & 0,144 & 0,046 \\
\hline
\end{tabular}

Залежність $F_{z}$ від швидкості різання визначали за постійних значень глибини різання $t=0,75$ мм і подачі $S=0,74$ мм/об (табл. 5). 3 отриманих даних можна зробити висновок, що значення $F_{z}$ для всіх досліджуваних матеріалів зростає у разі збільшення швидкості різання до $1600 \mathrm{~m} / \mathrm{c}$, а при $V=2000 \mathrm{~m} / \mathrm{c}$ - різко спадає до значень, що відповідають $V=800 \mathrm{~m} / \mathrm{c}$. Якщо за швидкості різання $800 \mathrm{M} / \mathrm{c}$ і $2000 \mathrm{~m} / \mathrm{c}$ значення $F_{z}$ практично не відрізняються для всіх матеріалів, то за швидкостей $1250 \mathrm{M} / \mathrm{c}$ і $1600 \mathrm{~m} / \mathrm{c}$ проявляється результат нанесення йонно-плазмових покриттів: сила різання зменшується в $1,1 \ldots 1,5$ раза.
Табл. 5. Залежність $F_{z}$ від швидкості різання

\begin{tabular}{|c|c|c|c|c|c|c|}
\hline $\begin{array}{c}\text { Частота } \\
\text { обертан- }\end{array}$ & $\begin{array}{c}\text { Швид- } \\
\text { ність рі- }\end{array}$ & \multicolumn{5}{|c|}{ Головна складова сили різання $F_{z}$} \\
$\begin{array}{c}\text { деля, } \\
\text { об/хв }\end{array}$ & $\begin{array}{c}\text { зання } V \\
\text { м/с }\end{array}$ & P6М5 & $\begin{array}{c}\text { Р6М5+ } \\
\text { КІБ1 }\end{array}$ & $\begin{array}{c}\text { Р6М5+ } \\
\text { КІБ2 }\end{array}$ & $\begin{array}{c}\text { Р6М5+ } \\
\text { КІБ3 }\end{array}$ & $\begin{array}{c}\text { Р6М5+ } \\
\text { КІБ4 }\end{array}$ \\
\hline 800 & 7,5 & 33 & 31 & 30 & 32 & 29 \\
\hline 1250 & 11,8 & 80 & 63 & 57 & 70 & 54 \\
\hline 1600 & 15,0 & 96 & 79 & 73 & 87 & 69 \\
\hline 2000 & 18,8 & 32 & 31 & 30 & 31 & 30 \\
\hline
\end{tabular}

Залежність $F_{z}$ від глибини різання визначали за постійних значень швидкості різання $V=7,5 \mathrm{~m} / \mathrm{c}(n=$ 800 об./хв) і подачі $S=0,74$ мм/об. (табл. 6). Якщо за мінімальних заданих значень глибини різання $0,25 \mathrm{i}$ 0,5 мм значення $F_{z}$ практично однакові для всіх матеріалів, то зі збільшенням глибини зростає різниця між незміцненим і зміцненими різцями. За максимальної заданої $t=1$ мм сила різання у різців 3 покриттями менша в 1,2 ..1,3 раза, що можна пояснити більшою швидкістю зростання радіуса затуплення незміцненого різця за мірою заглиблення в матеріал заготовки.

Табл. 6. Залежність $F_{z}$ від глибини різання

\begin{tabular}{|c|c|c|c|c|c|}
\hline $\begin{array}{c}\text { Глибина } \\
\text { різання } \\
t, \text { мм }\end{array}$ & \multicolumn{5}{|c|}{ Головна складова сили різання $F_{z}$} \\
\cline { 2 - 6 } & P6М & $\begin{array}{c}\text { P6М5+KI } \\
\text { Б1 }\end{array}$ & $\begin{array}{c}\text { P6М5+KI } \\
\text { Б2 }\end{array}$ & $\begin{array}{c}\text { P6M5+KI } \\
\text { Б3 }\end{array}$ & $\begin{array}{c}\text { P6M5+KI } \\
\text { Б4 }\end{array}$ \\
\hline 0,25 & 6 & 6 & 6 & 6 & 6 \\
\hline 0,5 & 17 & 16 & 16 & 17 & 16 \\
\hline 0,75 & 33 & 31 & 30 & 32 & 28 \\
\hline 1 & 50 & 42 & 40 & 44 & 38 \\
\hline
\end{tabular}

Залежність $F_{z}$ від величини подачі визначали за постійних значень швидкості різання $V=7,5 \mathrm{~m} / \mathrm{c}(n=$ 800 об./хв) і глибини різання $t=0,75$ мм (табл. 7). Сила різання зростає для всіх досліджуваних матеріалів зі збільшенням величини подачі. Проаналізувавши отримані результати, можна констатувати, що зміцнювальний ефект від нанесення покриттів за різних значень подачі $є$ мінімальний, порівняно з їх впливом на зменшення $F_{z}$ під час зміни швидкості та глибини різання від 1,13 для $S=1,04$ мм/об. до 1,17 для $S=0,74$ мм/об.

Табл. 7. Залежність $F_{z}$ від величини подачі

\begin{tabular}{|c|c|c|c|c|c|}
\hline \multirow{2}{*}{$\begin{array}{c}\text { Подача } \\
S \text { мм/об }\end{array}$} & \multicolumn{5}{|c|}{ Головна складова сили різання $F_{z}$} \\
\cline { 2 - 6 } & Р6М & $\begin{array}{c}\text { P6М5+КІ } \\
\text { Б1 }\end{array}$ & $\begin{array}{c}\text { Р6М5+KI } \\
\text { Б2 }\end{array}$ & $\begin{array}{c}\text { P6М5+KI } \\
\text { Б3 }\end{array}$ & $\begin{array}{c}\text { P6M5+KI } \\
\text { Б4 }\end{array}$ \\
\hline 0,28 & 11 & 9 & 8 & 10 & 8 \\
\hline 0,52 & 17 & 16 & 15 & 16 & 15 \\
\hline 0,74 & 33 & 30 & 29 & 31 & 28 \\
\hline 1,04 & 36 & 34 & 33 & 35 & 32 \\
\hline
\end{tabular}

Висновки. Результати проведених досліджень засвідчують, що нанесення вакуумних йонно-плазмових покриттів на інструмент, що працює в контакті з деревиною, істотно зменшує такі показники, як силу тертя, інтенсивність зношування та силу різання. Виявлено, що під час тертя поперек волокон діапазон зміни сили тертя залежно від розташування зразка за висотою стовбура не корелює 3 діапазоном зміни твердості. Для визначення відхилення від очікуваного значення сили тертя введено коефіцієнт відповідності. Результати досліджень з визначення інтенсивності зношування та сили тертя показали, що значення цих величин зменшуються у послідовності $(\mathrm{Ti}-\mathrm{Ni}-\mathrm{N})-(\mathrm{TiN})-(\mathrm{Ti}+\mathrm{TiN})-(\mathrm{Ti}-\mathrm{Ni}-$ $\mathrm{N}+\mathrm{TiN})$ за всіх варіантів співвідношення режимних параметрів різання. 


\section{Перелік використаних джерел}

Bilous, O. V., Holubets, V. M., Hasii, O. B., \& Yuha, O. Y. (2001). Vplyv rezhymiv rizannia na stiikist instrumentu pry tochinni derevyny. Scientific Bulletin of UNFU, 11(1), 88-39. [In Ukrainian].

Bilous, O. V., Holubets, V. M., Yuha, O. Y., \& Hasii, O. B. (1999). Vplyv vydu nanesenoho pokryttia na trybotekhnichni vlastyvosti rizhuchoho instrumentu. Scientific Bulletin of UNFU, 9(5), 239245. [In Ukrainian].
Sopushynskyi, I. M. (1999). Statychna tverdist derevyny buka v Ukrainskykh Karpatakh. Scientific Bulletin of UNFU, 9(12), 249-255. [In Ukrainian].

Ugolev, B. N. (2001). Drevesinovedenie s osnovami lesnogo tovarovedeniia: uchebnik dlia lesotekhnicheskikh vuzov. (3rd ed.). Moscow: MGU, 340 p. [In Russian].

\section{ВЛИЯНИЕ ЗОНАЛЬНОСТИ СТВОЛА НА ТРИБОТЕХНИЧЕСКИЕ ХАРАКТЕРИСТИКИ ПАРЫ ТРЕНИЯ "ДРЕВЕСИНА - СТАЛЬ С ИОННО-ПЛАЗМЕННЫМ ПОКРЫТИЕМ"}

Приведены результаты исследований силы трения, интенсивности износа и силы резания стали Р6М5 с ионно-плазменными покрытиями. Показано, что их нанесение на инструмент, работающий в контакте с древесиной, существенно уменьшает эти показатели. Обнаружено, что диапазон изменения силы трения вдоль волокон в зависимости от расположения образца по высоте ствола коррелирует с диапазоном изменения торцевой твердости, а уменьшение силы трения инденторов с ионно-плазменными покрытиями по сравнению с другими методами упрочнения не зависит от того, с какой высоты ствола взят образец и составляет $1,5 \ldots 2,9$ раза для дуба; $1,5 \ldots 3,1$ - для бука; $1,3 \ldots 3,1$ - для сосны; $1,4 \ldots 3,5$ - для пихты. Установлено, что при трении поперек волокон диапазон изменения силы трения в зависимости от расположения образца по высоте ствола не коррелирует с диапазоном изменения твердости, то есть в лиственных пород сила трения меньше от того значения, которое можно было бы спрогнозировать, основываясь на соотношении твердости образцов в различных частях ствола. Для определения отклонения от ожидаемого значения силы трения введено коэффициент соответствия. Приведены причины относительного уменьшения сопротивления трению. Выяснено, что при трении индентора с покрытием по влажной древесине сила трения уменьшается для всех исследуемых пород на любой высоте ствола в 1,7 .. 2,3 раза. Наименьшее значение силы трения $0,1 \mathrm{H} \cdot 10^{-2}$ зафиксировано в паре трения "покрытие Ti-Ni-N+TiN - образец из верхней части ствола пихты" после шести проходов индентора вдоль волокон. Результаты исследований по определению интенсивности износа и силы трения показали, что значения этих величин уменьшаются в последовательности $(\mathrm{Ti}-\mathrm{Ni}-\mathrm{N})-(\mathrm{TiN})-(\mathrm{Ti}+\mathrm{TiN})-(\mathrm{Ti}-\mathrm{Ni}-\mathrm{N}+\mathrm{TiN})$ при всех вариантах соотношения режимных параметров резания.

Ключевые слова: сила трения; высота ствола; индентор; коэффициент соответствия; интенсивность износа; сила резания.

O. B. Hasiy', I. M. Sopushynskyy', O. V. Bilous ${ }^{2}$

${ }^{1}$ Ukrainian National Forestry University, Lviv, Ukraine

${ }^{2}$ Lviv Polytechnic National University, Lviv, Ukraine

\section{EFFECT OF TRUNK ZONALITY ON TRIBOTECHNICAL CHARACTERISTICS OF FRICTION PAIR "WOOD - STEEL WITH ION-PLASMA COATING"}

The results of the conducted researches show that the evaporation of vacuum ion-plasma coatings on a tool working in contact with wood significantly reduces such indicators as friction force, wear intensity and cutting force. It is found that the range of change of the friction force along the fibres, depending on the location of the specimen on the height of the trunk, correlates with the range of change of the face hardness, and the decrease in the friction force of indenters with ion-plasma coatings in comparison with other methods of strengthening does not depend on what height of the trunk is taken specimen and is from 1.5...2.9 times for oak; $1,5 \ldots 3,1$ - for beech; $1.3 \ldots 3.1$ - for pine; $1,4 \ldots 3,5$ - for fir. In the case of friction across the fibres, the range of change on the friction force, depending on the location of the specimen on the height of the trunk, does not correlate with the range of hardness change, that is, in deciduous species the friction force is less than that which could be predicted based on the ratio of specimens hardness in different parts of the trunk. To determine the deviation from the expected value of the friction force, the coefficient of compliance is introduced. The reasons for the relative reduction of resistance to friction may be due to the following factors. The content of lignin, which determines the strength of trunks, in wood of pine and fir ranges from 26 to $30 \%$, and in oak and beech is $20 \ldots 24 \%$. All the analyzed species contain gemicellulose about the same amount $-22 \ldots 26 \%$. It consists of hexosans $\left(\mathrm{C}_{6} \mathrm{H}_{10} \mathrm{O}_{5}\right)_{\mathrm{n}}$ and pentosans $\left(\mathrm{C}_{5} \mathrm{H}_{8} 0_{4}\right)_{\mathrm{n}}$. But the content of hexosans with a higher molecular weight in coniferous species is twice as large as in deciduous. The mechanical function in coniferous species is also made of tracheid fibres, the length of which is $4 \ldots 6 \mathrm{~mm}$. Libriform fibres that perform a similar function in deciduous, have a length of up to $1 \mathrm{~mm}$. Peculiar ribs of hardness of hardwood trees are core rays. In oak their volume reaches $30 \%$. But they are oriented in the radial direction, so during the motion of the indenter across the fibres do not substantially impede its displacement. When friction of the indenter with a coating on wet wood, the friction force decreases for all investigated species at any height of the trunk in $1.7 \ldots 2.3$ times, which can be explained by the fact that moisture acts as a lubricant. The least value of the friction force of $0.1 \mathrm{H} \cdot 10^{-2}$ was recorded in the friction pair "Ti-Ni-N+TiN coating - a specimen from the upper part of the fir trunk" after six passes of the indenter along the fibres. The results of studies on determining of wear intensity and friction force have shown that its values decrease in the sequence $(\mathrm{Ti}-\mathrm{Ni}-\mathrm{N})-(\mathrm{TiN})-(\mathrm{Ti}+\mathrm{TiN})-(\mathrm{Ti}-\mathrm{Ni}-\mathrm{N}+\mathrm{TiN})$ in all variants of the ratio of regime cutting parameters.

Keywords: friction force; height of the trunk; indenter; coefficient of compliance; wear intensity; cutting force. 